\title{
RITOS DA MEMÓRIA: TRAJETÓRIAS E EXPERIÊNCIAS SOBRE A DITADURA MILITAR
}

João Paulo Macedo e Castro

Meu pai faleceu no dia 04 de outubro de 1984. Durante muitos anos eu acreditei que, para entender a sua morte, deveria restituir sua trajetória, seguir cronologicamente suas experiências, entender suas escolhas e os caminhos que levaram à sua morte. Entretanto, algumas peças não se encaixavam, continuavam não explicando o que o teria levado a cometer um ato suicida (entendimento sobre sua morte recorrente até hoje). Em 2010, Flávia, minha irmã, lançou o premiado documentário Diário de uma busca, ${ }^{1}$ no qual narra as histórias e as estórias do nosso pai, da nossa família, de seus amigos, da sua morte. A partir do filme, e principalmente movido pela repercussão, os usos, os comentários suscitados em blogs, artigos de jornais, entrevistas etc., pude então esboçar o que talvez estivesse faltando para mim. Sempre tive a sensação de que havia um descompasso entre o que era dito sobre meu pai e os sentidos que eu atribuía à sua vida/morte. Era como se para os outros houvesse uma sucessão de eventos encadeados de forma linear e quase autoexplicativos. Com início, meio e fim. Como se sua história obedecesse a um roteiro previamente instituído, e o sentido de ações, escolhas e emoções produzidas ao longo da sua vida pudessem ser ressignificados de forma clara e contínua dentro de um determinado campo de possibilidades. O exercício de pensar sua morte tornou-se então para mim a busca por uma perspectiva atemporal, em que o cruzamento entre passado, presente e futuro produzisse algum tipo de entendimento, e não necessariamente uma explicação.

No dia 31 de abril de 2012, em frente ao Clube Militar do Rio de Janeiro e em meio à comemoração do $48^{\circ}$ aniversário do golpe que depôs o presidente João Goulart, jovens militantes, ex-exilados, filhos e netos de presos políticos e desaparecidos no período do governo militar manifestavam-se 
contra o ato. E, como parte da ritualização do evento, projetaram no muro do clube trechos do filme Diário de uma busca, que narrava, do ponto de vista de minha irmã, a trajetória de nosso pai, Celso Castro.

Celso foi militante do Partido Operário Comunista (POC) nos anos 1970 e, como muitos militantes da época, exilou-se no Chile, na Argentina, em Paris e na Venezuela, retornando ao Brasil em 1979 com a Lei de Anistia. ${ }^{2}$ Seu percurso poderia confundir-se com outras tantas trajetórias de ex-militantes e ex-exilados que tiveram que reordenar suas vidas após a experiência do exílio político, se não fosse a sua morte em 1984 em circunstâncias misteriosas.

Outubro, 1984. Celso Castro, jornalista com uma longa história de militância de esquerda, é encontrado morto no apartamento de um ex-oficial nazista, onde entrou à força. A polícia sustenta que se trata de um suicídio. O episódio, digno de um filme de suspense, é o ponto de partida de Flavia, filha de Celso e diretora do filme, que decide reconstruir a história da vida e da morte do homem singular que foi o seu pai (Sinopse do filme Diário de uma busca).

No início do filme, Flavia expõe suas motivações e sentimentos em relação à história de nosso pai: "Durante muito tempo pensar sobre meu pai significava pensar sobre sua morte. Como se pelo seu enigma e pela sua violência ela tivesse apagado a sua história, e junto com ela parte da minha vida". O filme produz de forma muito sensível em sua narrativa uma sobreposição de tempos e vozes conectando as diferentes experiências vividas por Celso. E também estabelece um sentido à sua trajetória, que passa a ser apropriada e ressignificada pelos contextos diversos pelos quais circulou.

Neste artigo, pretendo discutir como experiências como as de Celso, mesmo quando percebidas como práticas individuais, singulares e contextuais, tendem a ser, em alguns contextos, indexadas a certos esquemas de pensamento, e às supostas condições objetivas de tais experiências. Inicialmente, apresento a recepção social obtida pelo filme Diário de uma busca, expressa em matérias de jornais, blogs e em debates, que produziu narrativamente um determinado lugar de Celso na luta política do Brasil nos anos de 1970. Os eventos contados no filme são interpretados por essa narrativa à luz das grandes questões colocadas para uma geração de militantes políticos que viveu os 21 anos de ditadura (luta armada, revolução, resistência, perda, exílio, morte, prisão), produzindo certo sentido biográfico à trajetória de Celso (Bourdieu 2008; Levi 2008).

Em seguida, através da análise da cobertura jornalística da morte de Celso, analiso as interpretações produzidas sobre as circunstâncias que a envolveram. Por fim, recorro às cartas enviadas por Celso a familiares e 
amigos durante os anos de 1970/1980, buscando sentidos e significados de suas experiências capazes de oferecer outros caminhos de entendimento da sua trajetória. Por meio do estudo dessas cartas, pretendo demonstrar como certas "experiências singulares" (Dewey 2010), ${ }^{3}$ expressas em determinadas ações promovidas pelos indivíduos podem produzir sentidos diversos e, com isso, desestabilizar o entendimento de trajetórias e biografias.

Parto, assim, da premissa da indissociabilidade, que Bourdieu (2009:89) definiria como "as disposições inculcadas nas condições objetivas" que geram também "disposições objetivas" nas práticas individuais. Mas busco também olhar para aquelas experiências produzidas no vácuo ou, nos termos de Turner (1974), na "liminaridade", onde as "disposições inculcadas", os "esquemas de pensamentos" e as dimensões "estruturais" da ação humana não respondem como instrumentos analíticos para dar conta da complexidade da experiência. Pois, enquanto dimensão suspensa, indefinida e instável, não obedece aos trâmites científicos, aos conceitos e às categorias de apreensão, tradução e comunicação forjados para ordená-las. No entanto, produzem sentidos, pois são "experiências vividas" (Dilthey 2010). ${ }^{4}$ E, se são vividas, produzem significados e merecem ser objeto de entendimento.

\section{Mitos da narrativa, tempos e significados}

A geração do teu pai sonhou alto e perdeu. Mas existem sucessos medíocres e lindos fracassos. O teu filme é sobre esses segundos. Acho que você realizou a melhor crônica do exílio que conheço (João Moreira Salles, material de divulgação do filme Diário de uma busca, 2010).

O filme mostra uma geração de militantes que deu tudo. Foi uma forma de revolução que fracassou (Alain Krivine, Folha de São Paulo, 16/07/2011).

O primeiro texto acompanha o cartaz do filme Diário de uma busca. O segundo é um trecho de uma entrevista do ex-militante da Liga Comunista Revolucionária francesa (LCR), ${ }^{5}$ amigo de Celso Castro. As duas passagens sintetizam bem os sentidos que foram atribuídos ao filme, assim como estabelece o lugar que ele foi ocupando no campo das narrativas sobre o período da geração que combateu a ditadura militar. Temas como os sonhos, o exílio, as perdas, os sucessos, os fracassos, os afetos, as angústias, as dores do retorno e a luta armada dominaram boa parte de suas resenhas e críticas. ${ }^{6}$ Em praticamente todas estas resenhas prevalecia a oposição entre sonho e fracasso. Como se a morte de Celso fosse um caminho pos- 
sível para aqueles que no passado "sonharam alto" ou "deram tudo" por um projeto que fracassou.

Pude participar de quatro debates, com públicos bem distintos. ${ }^{7}$ Em que pesem as particularidades e as especificidades de cada plateia, observei que em todas as projeções e nos debates estabeleceu-se um elo afetivo entre o público e os diferentes momentos da trajetória de Celso. Como se a singularidade da sua existência se fundisse às singularidades de cada um, fornecendo à experiência vivida por Celso uma dimensão coletiva, formadora de uma continuidade entre as diferentes experiências políticas do passado e as do presente. Como se as motivações e as expectativas que levaram Celso a ingressar na luta política e posteriormente na luta armada fossem as mesmas que hoje jovens militantes, ou mesmo velhos militantes, creditam à sua imersão/permanência na política.

Estabelecia-se desta forma um sentido épico, histórico, transcendente que criava uma comunhão de solidariedade e de euforia com todas as experiências consideradas revolucionárias, humanistas e libertárias promovidas ao longo dos tempos. Das barricadas de 1848 na França, passando pelas revoluções Russa de 1917, Cubana de 1957 e Nicaraguense de 1978. Em uma espécie de catarse coletiva, cada indivíduo parecia encontrar o conforto na experiência e na vivência alheia, forjando o espírito da comunhão. Como num templo, as emoções individuais se confundiam na grande oração coletiva. O indivíduo deixava de ser singular e sua experiência não mais lhe pertencia. Nesta dimensão ocorriam a indexação e a interpretação das ações de Celso. A sua trajetória deixava de ser individual e se inscrevia em uma herança, pertencia a uma certa memória, distinta, singular. De alguma forma estabeleceu-se um canal de "comunicação para a consciência histórica" (Diehl 2002:116). As emoções provocadas pelo filme em cada um eram únicas, mas se filiavam a uma perspectiva histórica compartilhada.

Poderíamos então falar junto com Giovanni Levi que, a partir desta perspectiva, "uma vida não pode ser compreendida unicamente através de seus desvios ou singularidades, mas, ao contrário, mostrando-se que cada desvio aparente em relação às normas ocorre em um contexto histórico que o justifica" (Levi 2008:176). A biografia de Celso era reconstruída e o significado das suas experiências, interpretados, produzindo um certo sentido biográfico à sua trajetória. ${ }^{8}$ No entanto, como nos lembra Nora (1993), “a memória é vida sempre carregada por grupos vivos". E é nos embates entre lembranças e esquecimentos, usos e manipulações que são produzidos os sentidos e as interpretações. O caminho a ser percorrido neste artigo será o de tentar responder à seguinte pergunta: É possível oferecer outro tipo de entendimento para a vida e a morte de Celso? 


\section{$O$ assalto a Moinhos de Vento}

Celso Afonso Castro, jornalista, ex-exilado e ex-militante do POC nos anos 1970, tinha 41 anos quando morreu em um suposto assalto no bairro Moinhos de Vento, na cidade de Porto Alegre, no dia 04 de outubro de 1984. Junto com ele estava o amigo Nestor Heredia, ex-exilado e ex-militante da Vanguarda Armada Revolucionária Palmares (VAR-Palmares), que também foi morto. O evento trágico foi tratado pela mídia e pela polícia ${ }^{9}$ como uma excepcionalidade, pois os dois assaltantes eram pessoas das camadas médias e altas da população. Nestor era professor universitário de sociologia e Celso jornalista/economista e assessor de um vereador do Partido Democrático Trabalhista (PDT). Os proprietários do apartamento invadido eram os alemães Rudolf e Ursula Goldbeck. Rudolf era ex-cônsul do Paraguai, exportador de tabaco e suspeito de ter sido um antigo integrante da Luftwaffe (força área alemã do período nazista). Na época do evento, o genro de Celso era responsável pela conta de Rudolf em uma corretora de valores, fato que comprovaria a existência de um vínculo entre os supostos assaltantes e a vítima. Entre os dias 05 e 10 de outubro foram publicadas pelo principal jornal de Porto Alegre, o Zero Hora $(\mathrm{ZH})$, diversas informações e interpretações sobre o contexto das mortes, e formulados os eixos centrais que forneceriam a base da narrativa sobre seu entendimento.

No dia 05 de outubro de 1984 - dia seguinte ao "assalto" — o jornal ZH estampava as seguintes manchetes: "Ex-exilados tentaram o assalto. Um deles era assessor de vereador"; "Assaltantes se suicidam no apartamento cercado". Os termos "ex-exilado" e "assaltante" foram então os primeiros marcadores utilizados para identificar os agressores. A estes foram em seguida acrescentados outros na continuação da matéria: "Os assaltantes não eram criminosos comuns. Um deles, jornalista e o outro comerciante" [...] "tratava-se de Celso Afonso Gay de Castro, jornalista de tradicional família gaúcha [...] ambos eram muito conhecidos nos meios sociais da cidade" [...] "ambos foram exilados políticos após atuação como guerrilheiros urbanos". Os marcadores "criminosos comuns", "jornalista/comerciante", "tradicional família gaúcha" e "guerrilheiros urbanos" e suas combinações possíveis passariam então a orientar a investigação policial, o acompanhamento da imprensa e o posicionamento dos amigos e familiares, fornecendo as linhas principais para a elucidação do caso que ficou conhecido como o "assalto no Moinhos de Vento". 


\begin{tabular}{|c|c|}
\hline Jornais & Título das matérias \\
\hline 05.10.1984 (Zero Hora) & $\begin{array}{l}\text { Ex-exilados tentaram assalto. Um deles era assessor de } \\
\text { vereador. } \\
\text { Policiais tentam um diálogo sem sucesso. } \\
\text { Assassinato e suicídio. } \\
\text { Assaltantes se suicidam no apartamento cercado. }\end{array}$ \\
\hline 06.10 .1984 (Zero Hora) & $\begin{array}{l}\text { Mistérios do assalto no Moinhos de Vento. } \\
\text { Assaltante matou o parceiro e depois se suicidou. } \\
\text { Motivos políticos também sob exame. } \\
\text { Surgem também algumas hipóteses estranhas que a } \\
\text { polícia está investigando. } \\
\text { Para a polícia assalto ainda não tem conotações políticas. } \\
\text { Do assalto (editorial policial). }\end{array}$ \\
\hline 07.10.1984 (Zero Hora) & $\begin{array}{l}\text { Ligações e a vida de Rudolf investigadas. } \\
\text { Continua o mistério sobre o ataque. }\end{array}$ \\
\hline 08.10.1984 (Zero Hora) & $\begin{array}{l}\text { Delegado diz que o inquérito está na fase final. } \\
\text { Ex-cônsul está praticamente fora de perigo. }\end{array}$ \\
\hline 09.10.1984 (Zero Hora) & $\begin{array}{l}\text { Para delegado invasão no sul não foi política. } \\
\text { Assaltante conhecia ex-cônsul do Paraguai. } \\
\text { Antigos negócios ligavam Celso a Rudolf. } \\
\text { Delegado recebeu os laudos da necropsia. }\end{array}$ \\
\hline 09.10.1984 (Folha de São Paulo) & Para delegado, invasão no sul não foi política. \\
\hline 12.10.1984 (Folha de São Paulo) & Ex-cônsul baleado no sul retorna ao estado de coma. \\
\hline
\end{tabular}

A partir desses marcadores é possível identificar como os protagonistas iam sendo classificados e o ato explicado. Para efeito analítico, podemos separar as interpretações em quatro grandes eixos.

O primeiro se fundava nos marcadores "tradicional família gaúcha" e "jornalista/comerciante". Tais atributos justificavam a surpresa estampada pelo jornal do envolvimento dos dois no ato, já que ele não corresponderia ao comportamento esperado, tornando-se, assim, um ato extraordinário. Este primeiro eixo foi formulado principalmente nas primeiras matérias publicadas pelo jornal ZH. 
Já os marcadores "ex-exilado" e "guerrilheiro urbano" abriam um segundo eixo explicativo. A partir deles, a ação estaria, sim, no rol das possibilidades do comportamento dos envolvidos, pois se encaixava no imaginário sobre suas experiências em ações de confronto armado e de enfrentamento da ordem. Era valorizada nesta linha de entendimento a existência de uma familiaridade com a violência e com a prática de atos considerados ilegais e/ ou criminosos. Este segundo eixo foi formulado principalmente pela polícia e também aparece nos relatos de alguns jornalistas que acompanharam o caso (em especial, o editorial do ZH do dia 06.10.1984).

Já o terceiro eixo se fundava em uma combinação dos dois primeiros, com certas variações e nuances. Nesta perspectiva, mais difusa e de difícil explicitação, procurava-se separar o ato praticado por Celso e Nestor dos valores e da ética promovidos pela militância política, visto que o ato teria sido identificado como uma ação de violência desprovida de sentido político. Esta linha de interpretação aparece de forma difusa em alguns depoimentos de amigos/conhecidos de Celso coletados por jornalistas (ver matérias ZH do dia 06.10.1984), assim como nos debates promovidos pela imprensa na qualificação da natureza do crime. "Crime político" ou "crime comum"?

Vale notar que nos documentos produzidos pelo Departamento de Ordem Política e Social (DOPS) que monitorou as matérias publicadas pela imprensa, acompanhou o velório e o enterro, os investigadores assinalaram que havia um "certo incômodo nas lideranças de esquerda [...] com a tentativa de transformar o que seria um crime comum em um crime político". Esta falta de sentido no ato, só poderia, então, ser explicada, do ponto de vista psicológico. Nestes termos, ganhou visibilidade o fato de Celso estar em tratamento psiquiátrico e em tratamento contra o alcoolismo. Segundo alguns depoimentos prestados ao delegado durante o inquérito, Celso teria se afastado do "convívio familiar", tendo comportamentos "anormais" provocados pela sua dificuldade de adaptação após o exílio (DPM/DI/Delegacia de roubos. Relatório, 1984).

Nesta perspectiva, o ato de 04 de outubro representaria a incapacidade de Celso de refazer sua vida em um contexto de derrota política. Esta tese, compartilhada por outros ex-militantes e ex-exilados e amplamente citada na literatura sobre o tema, oferecia um conjunto de possibilidades de entendimento/explicação de certas ações traumáticas e dolorosas praticadas por ex-militantes. ${ }^{10}$

O inusitado assalto talvez tenha uma explicação, pois em poder [de um deles] foi encontrado um atestado médico confirmando que ele estava se submetendo a um tratamento psiquiátrico $(\mathrm{ZH}, 08.10 .1984)$. 
Compreender as motivações e a condição psicológica de Celso significava estabelecer o seu lugar no interior da tradição da militância política de esquerda, ${ }_{11}^{11}$ especialmente nesse momento de rearranjo e de redefinição das suas práticas, estratégias e posicionamentos em face da nova conjuntura pós-anistia. A ação praticada por Celso e Nestor mostrava um distanciamento dos sentidos e dos significados atribuídos à política brasileira naquele momento. Era preciso então encontrar uma forma de explicar o comportamento dos dois que permitisse que o espírito pregado pela militância e pela nova estratégia política das esquerdas não fosse atingido, e que ele continuasse a ser organizado e desenvolvido para poder enfrentar os novos desafios.

Em 1984, a esquerda brasileira ainda estava se constituindo como força política e força eleitoral. Em Porto Alegre, o PT (no qual militavam alguns ex-companheiros de Celso) e o PDT (partido do vereador Valneri Antunes, em que trabalhava Celso) disputaram as eleições de 1982, sendo que o PDT se tornou a terceira maior força política do estado, recebendo $22 \%$ dos votos e o PT, 1,5\%. E nas eleições de 1982 concorreu ao Senado Federal pelo PT o ex-colega de Celso, Raul Pont. Ou seja, havia no Rio Grande do Sul, assim como em outros estados brasileiros, uma preocupação das forças de esquerda de se viabilizarem enquanto forças eleitorais (Meneguello 1989; Sarti 1998; Montenegro 2009). No início dos anos de 1980, o Brasil ainda vivia sob o manto de uma Lei de Segurança Nacional (Lei 6.620), o presidente João Figueiredo tendo sido empossado por Ernesto Geisel em 1979. Em 1980 explode uma carta-bomba na sede da Ordem dos Advogados do Brasil (OAB), no Rio de Janeiro. Em 1981, em um evento de comemoração ao Dia do Trabalhador, uma outra bomba explode no estacionamento do Riocentro (RJ).

Estas e outras ações contra entidades e partidos políticos tradicionais (ABI, PCB) produziram um clima de insegurança e incerteza quanto aos caminhos da abertura política. A grande imprensa, de forma genérica, declarava que tais atentados haviam sido elaborados por setores que se colocavam contra a anistia que estava em curso. Neste sentido, é plausível entender que ações violentas com conotações políticas nos anos 1980 produzissem sensações de medo e incerteza quanto aos possíveis efeitos e às consequências para a frágil negociação pela abertura política ainda em curso. No ano de 1986, um assalto ao posto do Banco do Brasil no interior da Bahia, praticado por ex-integrantes do PCBR e filiados do Partido dos Trabalhadores, levou o partido a expulsar os militantes e a afirmar que tais práticas não eram aceitas no interior do partido (Veja, 23.04.1986). A possibilidade de dar uma conotação política ao "assalto no Moinhos de Vento" poderia comprometer a estratégia política de viabilidade eleitoral dos partidos de esquerda. 
Se não era possível compreender toda a dramaticidade do evento, era importante ao menos explicá-la e indexá-la a um campo passível de entendimento. $\mathrm{O}$ caso foi encerrado pelo delegado titular com a seguinte conclusão:

[Em] face do exposto, ficou claro que NESTOR GUIMARÃES HEREDIA E CELSO AFONSO GAY DE CASTRO praticaram delito de roubo, previsto no artigo acima referido [artigo $157 \S 3^{\circ}$ ], permanecendo incógnita quanto aos reais motivos que levaram o ex-professor universitário e o jornalista a cometerem tal delito, levando-os, posteriormente à morte. Diante dos fatos aqui levantados, NESTOR e CELSO poderiam ter cometido o crime, por uma simples questão financeira, por motivos políticos, por vingança, ou ainda por ser a vítima um cidadão de passado político de direita, enquanto estes eram de esquerda, sendo que quanto às suas mortes poderia ter acontecido o suicídio de ambos ou, segundo a versão da Sra. URSULA, CELSO teria assassinado o companheiro e após se suicidado para não se entregar com vida à polícia (DPM/DI/Delegacia de roubos. Relatório, 1984).

Em contraposição a estas versões, a primeira esposa de Celso e seu companheiro, o ex-presidente da UNE (Jean Marc), produziram uma quarta interpretação, a do "crime político". Como mostram as matérias abaixo, a preocupação era oferecer uma outra imagem de Celso e Nestor, distinta daquela que vinha sendo postulada pela investigação policial, por alguns familiares e por colegas e amigos que centravam suas explicações no eixo fracasso/derrota/inadequação.

\begin{tabular}{|l|l|}
\hline 10.10.1984 (Folha de São Paulo) & $\begin{array}{l}\text { Família defende invasores da casa do ex-cônsul. } \\
\text { Ex-presidente da UNE questiona a versão policial } \\
\text { sobre invasão no RS. }\end{array}$ \\
\hline 17.10 .1984 (Isto É) & Crime incomum nos Moinhos de Vento. \\
\hline s/d (Pasquim) & Caso de polícia. \\
\hline Jan. 1985 (Folha de São Paulo) & Família de jornalista duvida de suicídio. \\
\hline s/d (O Jornal do Jockymann- RS) & Dois suicidados investigavam os nazistas no sul. \\
\hline
\end{tabular}

A variação desta interpretação rebatia duas argumentações importantes produzidas a partir do inquérito policial:

1. A motivação. De acordo com Jean Marc, em agosto de 1984, Celso foi ao Rio de Janeiro e, em uma conversa, revelou que estaria realizando um levantamento sobre a relação entre organizações de ex-nazistas e grupos paramilitares de direita para a redação de um livro. 
Não foi um assalto por dinheiro, como garante a polícia, mas uma tentativa de levantar extensa documentação vinculando organizações de ex-nazistas no Cone Sul com grupos paramilitares de direita que atuam na região (Folha de São Paulo, 10.10.1984). ${ }^{12}$

2. A tese do suicídio. De acordo com essa variação, no inquérito, as contradições mostravam-se muito grandes e não permitiam a afirmação com exatidão do ato de suicídio. Se os assaltantes conheciam tão bem os hábitos do casal, sabiam que não havia dinheiro no apartamento. As questões levantadas foram então: por que o material (em alemão) apreendido no cofre não foi disponibilizado para a imprensa e nem para o advogado da família? Onde estariam as condecorações e o uniforme do exército nazista vistos por jornalistas no apartamento? Por que, segundo alguns jornalistas que acompanharam os eventos, Rudolf falava o tempo todo "eu não gosto de Hitler!"?; Por que um dos laudos da balística apontava quatro disparos, enquanto alguns depoimentos indicavam que foram ouvidos oito disparos? Onde estava o exame de balística sobre a análise da relação entre os projéteis encontrados e as armas apreendidas? Por que o revólver dos policiais não foi periciado? Por que o proprietário do apartamento não foi ouvido, se já não se encontrava mais em coma? Por que o zelador que teria aberto a porta não foi ouvido? Por que alguns testemunhos afirmaram que a polícia arrombou a porta? Seria coincidência o delegado titular encarregado do caso ter sido integrante do DOPS?

A introdução da tese de que Celso estaria realizando uma investigação a respeito da relação de grupos de extrema direita com ex-nazistas trazia questões novas sobre o entendimento dos fatos ocorridos. Nesta perspectiva, Celso teria ido ao apartamento de Rudolf para procurar documentos e provas que contribuíssem para a sua investigação. O ato praticado passava a ter um sentido concreto, deixando de ser indexado como uma ação inconsequente e fruto de uma mente emocionalmente abalada, que não teria aguentado a desilusão depois do "fracasso" do "projeto político". Segundo este ponto de vista, estabelecia-se uma continuidade das trajetórias de Celso e Nestor com a tradição da esquerda revolucionária. Com esta variação, buscava-se oferecer uma nova interpretação não apenas sobre os atos praticados no dia 04 de outubro de 1984 por Celso e Nestor, mas também sobre suas biografias, sobre os sentidos das experiências vividas ao longo das suas trajetórias. A perspectiva de derrota/fracasso ou de inadequação por si só não explicaria a ação praticada.

As interpretações produzidas à época sobre a morte de Celso e a repercussão do filme da minha irmã fizeram com que, 29 anos depois, eu 
indagasse: afinal, o que foi derrotado e o que fracassou? Tentar responder a esta questão e produzir uma compreensão sobre a ação praticada no dia 04 de outubro exigem um entendimento não apenas sobre a trajetória de atuação política dos envolvidos, mas também sobre os diferentes significados e sentidos atribuídos a tais experiências.

\section{Trajetórias e experiências individuais: sentidos do exílio ${ }^{13}$}

Depois que passa a gente fica pensando... meu Deus como é que a gente aguentou, tanta coisa, tanto rompimento. Porque não era só a ausência, um rompimento todo de uma estrutura, política, familiar, tudo [...] foi sendo levado... (Zilda Castro, mãe de Celso). ${ }^{14}$

A militância política de Celso começou no ensino médio. Com alguns colegas que mais tarde também ingressariam na luta armada, ele havia participado de atividades em solidariedade a Cuba e de passeatas estudantis no início dos anos 1960. Em 1962, com 19 anos, ingressou no Partido Comunista do Brasil, no qual posteriormente participaria da facção Ala Vermelha até 1971, quando passou a fazer parte do POC. No mesmo ano é detido, abandona a corretora Mello\&Castro pertencente a seu pai, na qual trabalhava desde os 17 anos, e parte para o exílio com sua mulher. Primeiro vão para o Uruguai e, de lá, para o Chile, onde iniciam um período de oito anos de exílio que iria incluir também a França e a Venezuela.

O envolvimento de Celso em atividades políticas não proporcionou em si uma ruptura com os hábitos ou os valores do grupo familiar. Entretanto, a experiência do exílio e a adesão cada vez mais intensa ao projeto revolucionário produziram um reordenamento de sentimentos e intensificaram emoções e afetos, promovendo outras significações às relações e aos elos afetivos existentes, o que pode ser visto em algumas cartas enviadas por Celso à família durante o período do exílio.

O distanciamento produzido pelo exílio e a intensificação da experiência da militância, radicalizada nos países pelos quais passou, aproximaram Celso cada vez mais dos valores e dos sentimentos compartilhados pelos demais militantes envolvidos na luta política contra as ditaduras militares latino-americanas, ou na construção de experiências novas de organização política (como foi o caso do Chile, no governo socialista de Salvador Allende). Isto pode ser visto na carta enviada para sua mãe em 1973, ainda vivenciando a experiência do governo Allende antes do golpe de 11 de setembro de 1973 que instituiu o governo de Augusto Pinochet. 
Chile, 1973 (carta aos pais; um mês antes do golpe de Estado) Por aqui, em relação à família, não há novidades. Estamos mais ou menos bem instalados numa boa casa, com cachorros, gatos, patos, galinhas etc., e um enorme pátio para as crianças brincarem. E podem ficar tranquilos, pois as crianças agora têm uma casa normal, com pais normais e vão ao colégio normalmente. Eles estão muito satisfeitos da vida e tranquilos. Quanto a nós, estamos num ritmo de atividade violentíssimo. Realmente agora se pode dizer que não há mesmo tempo pra nada. É uma correria impressionante. Eu até perdi 20 quilos, o que é a prova definitiva de que o trabalho é grande. Também estamos estudando bastante. E o que é importante é que agora a gente começa a sentir que superou uma série de problemas, que está avançando, amadurecendo. E isto dá uma grande tranquilidade e segurança. É muito importante o cara sentir que está fazendo o que tem que fazer. E não porque não possa fazer outra coisa, mas porque está absolutamente convencido do que está fazendo, seguro de que sua opção é definitiva e consequente. E isso é mais ou menos o que acontece conosco hoje. A fase das fossas, dúvidas, vacilações já era, ficou pra trás há muito tempo. Assim, estamos bastante satisfeitos, perfeitamente integrados em um trabalho político muito concreto, com objetivos bem claros e definidos, e naturalmente, assumindo conscientemente todos os problemas e riscos da opção.

Pode-se supor que no período da vivência no Chile o afastamento do cotidiano familiar era substituído pela valorização e a intensificação dos vínculos com outros grupos e valores. ${ }^{15} \mathrm{O}$ primeiro não fora totalmente abandonado, mas era alimentado por cartas e pelo compartilhamento do crescimento das crianças. Como mostra o início da carta acima, existia uma necessidade de tranquilizar a família, afirmando que, se o caminho assumido no passado recente da atividade política tinha fugido de certa expectativa de "normalidade", esta mesma atividade, naquele presente, oferecia a oportunidade da construção de uma "vida normal".

A expectativa de construir uma vida normal em outros termos e princípios é reafirmada na sequência da carta. Nela percebe-se uma ratificação da adesão às possibilidades produzidas pela atividade política e, principalmente, a afirmação de que a normalidade da vida social pode ser efetivada e realizada através de outro projeto, de outra forma de existência. Tal entusiasmo parece indicar tratar-se de uma adesão existencial a valores, crenças e ações proporcionados por outra forma de comunhão. ${ }^{16}$

O golpe de Estado de 11 de setembro de 1973 no Chile produziu uma nova radicalização da luta política e um confronto mais ostensivo, em especial daqueles que estavam vivendo a experiência e as possibilidades de 
transformação política no país. E esta radicalização operou em dois sentidos. De um lado, a experiência vivida a partir do governo Allende não foi forte o suficiente para garantir uma transformação concreta e a efetivação de um novo projeto de sociedade, afetando moral e emocionalmente os militantes, mesmo que de formas diferentes. O aumento da repressão, a perseguição, os desaparecimentos e os assassinatos de militantes produziram também medo, insegurança, angústia e incertezas quanto à própria existência, ameaçada constantemente. A normalidade aparentemente sentida no passado recente de novo parecia estar sendo rompida. Num outro sentido, a radicalização produziu um sentimento maior de solidariedade, de empatia com os "companheiros" presos, assassinados e/ou desaparecidos, e de maior integração e reconhecimento com os que "continuam na luta". Os elos com os companheiros da militância se intensificaram e os sentidos atribuídos à ação política ganharam contornos mais fortes, radicais, promovendo senão um distanciamento maior das experiências primárias (elos familiares), pelo menos a sua inserção em novos sentidos.

\section{Paris 1975 (carta aos pais)}

Meus queridos,

Esta carta é só para explicar algumas coisas. Negócio seguinte: Não sei se vocês viram nos jornais (até agora só saiu uma pequena notícia no Zero Hora e no Estadão) ou ouviram falar do que aconteceu na Argentina. Cinco amigos, muito próximos, foram presos. Entre eles, três brasileiros, dos quais dois vocês conhecem muito bem. Trata-se do Flavio e da Maria Regina, filha do Pilla. O terceiro brasileiro chama-se Paranaguá, é filho de um embaixador. Ainda não sei como e por que eles caíram. De qualquer modo a barra é muito pesada. Pelo nome e pela proximidade dos outros dois, fiquei com medo que vocês se preocupassem por mim. Deu para entender? O problema é que o caldo engrossou violentamente para cima de nós outra vez.

A curto prazo, não houve nenhuma consequência direta. Afinal de contas, em Paris a gente está a salvo de uma série de riscos que a luta de classes na América Latina e muito particularmente na Argentina coloca para os militantes.

Ficamos evidentemente muito chocados com a situação difícil pela qual está passando gente muito bacana e muitíssimo amiga. Havia (sempre há em casos como estes) uma possibilidade de que os cinco fossem mortos. Agora há uma certa garantia de que estão vivos e de que o pior já passou. Muito provavelmente vão curtir uma cadeia de vários anos na Argentina. As vinculações deles conosco (comigo e com Sandra) e com outros amigos quase certamente vão aparecer no processo. O que vai ser uma merda bastante grande. Deve significar que a nossa permanência nas Europas (sic) forçosamente se prolongará, indefinidamente. 
O que é realmente uma merda, atrapalha todos os planos. Enfim, é a vida. Como dizia o outro, os acidentes acontecem.

A família do Flavio e a do outro brasileiro estão em Buenos Aires tentando localizá-los. Acho que a mãe da Maria Regina deve estar bastante abalada. Talvez fosse bom, se não for complicado, que vocês escrevessem para ela ou algo parecido. Sei lá, dando um pouco de apoio, solidariedade ou coisa que valha. Bem, é isso. Estava preocupado com os boatos que podem circular aí e pelas histórias que podem surgir de tudo isso. Por isto o telegrama e a carta. Tô muito deprimido para escrever mais. Quando a repressão se abate sobre gente chegada é muito duro. E o mínimo que posso dizer da Neneca e do Flavio é que são meus irmãos.

Percebe-se também que as certezas quanto ao "trabalho político, com objetivos bem claros e definidos", expostos na carta de 1972, já não correspondem ao sentimento do momento, e nem o futuro parece muito claro. O exílio passa a ser sentido como uma condição de desenraizamento mais efetivo e constante, acionando outras lembranças e afetos que as novas adesões desestruturadas pela repressão não eram capazes de suprir. O exílio atua nos sentimentos mais profundos, impondo contradições e tensões que marcam o indivíduo durante a situação de exílio e depois dela (Said 2003). Existe uma recorrência nos depoimentos de alguns ex-exilados de que a situação de exílio, a tortura, o desenraizamento e a morte de companheiros teriam provocado inúmeras dificuldades de adaptação, de recomeço após o exílio (Ridenti 2010; Rollemberg1999; Thiesen 2011). ${ }^{17}$ Então, os elos e as identidades primordiais da família são acionados como forma de reestruturar processos identitários fragmentados, destituídos e desvinculados do seu lugar de origem.

\section{Caracas, 1976 (carta à mãe)}

A morte do pai me causou uma impressão, trauma (ou seja lá o que isso queira dizer) que é difícil de expressar. Primeiro porque, talvez por estar longe, não estava, para nada, preparado para esta possibilidade. Por isso, quando falei com Iara e ela me deu a notícia, me pareceu uma coisa irreal, absurda. Depois tratei de falar contigo, comecei a pensar, a reflexionar, a rememorar. Me senti então, e me sinto ainda um pouco responsável, não diretamente de sua morte, mas por toda essa situação que evoluiu e foi se deteriorando a partir de um determinado momento e que envolveu a todos nós, membros do clã dos Mello Castro, dependentes de uma forma ou de outra do patriarca Fortunato. O sentimento de culpa que tenho não chega a ser neurose, mas seria uma reação que seria considerada normal pelos psiquiatras da vida, que seguramente tratariam de 
analisar os problemas subjetivos da relação entre pai e filho, ao nível de uma teoria geral, abstrata e reacionária. Mas, além disso, o que trato de pensar e de analisar é a influência que a personalidade do pai exerceu em cada um de nós. E como esta influência se exercia sobretudo pelo carinho e não pela força, o resultado é que a vida de cada um de nós (pelo menos no que se refere à minha vida estou seguro disso) estava ligada e interdependente da vida dele. Tudo que passava comigo, por exemplo, de alguma maneira tinha alguma consequência, ou melhor, algum reflexo na sua vida. E, em certo sentido, esta relação foi unilateral. Durante quase toda a minha vida, eu contei com a compreensão e solidariedade tua e do pai. Entretanto, a partir do momento em que saí daí, que coincide mais ou menos com o período do agravamento da crise, que vocês foram obrigados a enfrentar. Crise financeira, problemas de família etc. Eu nunca pude ajudá-los, ao menos com a presença física e a solidariedade concreta e objetiva, dividindo os problemas e as responsabilidades. Me angustia não haver estado aí, durante a doença e a hospitalização. De qualquer maneira, as culpas e neuroses de cada um não mudam nada, e a morte é sempre difícil de aceitar. O que resta é uma enorme tristeza, sentida e profunda, frente à impossibilidade de fazer algo, de aceitar a realidade.

E a vida vai seguindo seu fluxo. O tempo das certezas e da clareza ficou para trás, busca-se uma inserção e uma adaptação parcial à condição vivida. Parcial pois o projeto não foi abandonado, mas talvez apenas adiado, reformulado ou amadurecido. No entanto, era preciso (sobre)viver, retomar a "normalidade", o que permitiria a reflexão e a integração entre a situação concreta e a subjetividade produzida pela existência. A pergunta talvez que tenha que ser feita é: de que normalidade se tratava?

\section{Caracas, 1976 (carta à mãe)}

[...] O problema é que depois de seis anos fora a gente começa a ter uma vontade de voltar enorme e tá sempre alimentando a esperança de que as coisas melhorem. Mas, enfim, o negócio é ir aguentando as pontas e continuar dando volta, curtindo a saudade. Nossa vida aqui vai mais ou menos. Caracas é uma cidade desagradável. Suja, quente, não chove nunca, não tem água, é caríssima, tem carro demais, enfim, uma merda.

Do ponto de vista do trabalho a coisa vai mais ou menos. Tô esperando um emprego num instituto de pesquisa da Universidade. Já apresentei o projeto, foi aprovado, mas até agora nada de contrato. Trabalho como tradutor do francês ao espanhol. Agora estou traduzindo um livro sobre Humboldt e vão me pagar uns 2.500 dólares. Além do livro, faço traduções de artigos, fora revistas e coisas assim. É um trabalho às vezes interessante, e relativamente bem pago. Além 
disso, ocasionalmente participo em seminários sobre política e também me pagam um pouco. O resto do tempo dedico a minhas atividades não remuneradas, mas mais gratificantes, digamos. Fora esse problema, o resto vai bem. Tenho lido bastante e agora consigo me organizar melhor para escrever. Acho que são os anos, mas o fato é que estou mais tranquilo, mais maduro, bastante seguro e acho que agora já sei o que vou ser quando [for] grande.

A sucessão das cartas, com suas cores e tonalidades variantes, proporciona uma leitura tensa, pois os que ficaram no Brasil (principalmente a mãe e as irmãs de Celso) acompanham com apreensão sentimentos contraditórios, dificuldades, tensões, sofrimento, dor, alegrias e satisfação relatados. É uma leitura passiva, angustiante, exatamente pelo não acompanhamento dos eventos, das nuances da vida concreta. Nas cartas, os fatos e os eventos já estão classificados e ordenados em emoções e sentimentos. Não existe o compartilhamento da experiência em ação, a subjetividade é do outro. ${ }^{18} \mathrm{~A}$ cada carta enviada um novo capítulo foi escrito, um novo entendimento produzido, mas os eventos continuam distantes. A carta de 1976, na Venezuela, já é mais amena, paira a possibilidade de um encontro com uma certa "normalidade", talvez não mais a mesma sentida no Chile, mas uma nova, possível diante da situação da época. O desejo familiar é de que o tempo da liminaridade (como nos diria Turner) tenha sido superado, e o indivíduo possa ser (re)inserido no espaço do qual partiu.É o tempo de aplacar as fissuras produzidas pelas rupturas sucessivas, de restituir afetivamente os elos suspensos, transformados, ressignificados pelo tempo, pela distância.Desejo manifesto e não realizado, como nos lembra a mãe de Celso no início deste tópico.

\section{Os sentidos do retorno}

O retorno ao país de origem certamente foi um dos grandes desafios para muitos exilados e militantes políticos, como demonstram diferentes testemunhos e narrativas (Quadrat 2008; Rollemberg 1999, 2007; Ridenti 2010a). E para Celso foi muito concreto. O retorno às suas "raízes", aos familiares e amigos que ficaram deveria proporcionar, mesmo que parcialmente, alguma tranquilidade. Afinal, a dor e a saudade agora poderiam ser reconfortados e reconciliados. Como lembra Rollemberg, existia nos exilados uma aposta de que

A Anistia era, ao mesmo tempo, o fim e o começo. Promoveria a retomada de uma sequência interrompida. Pertencer, enfim, 'plena e verdadeiramente', a uma sociedade. Restabelecer uma identidade perdida, usurpada. Recuperar 
a capacidade de expressão e compreensão na língua materna. Reencontrar as origens, o meio onde se nasceu e se cresceu. Reunir partes fragmentadas. Retomar a luta. Reinserir-se na vida política do país. [Contudo,] se o fim do exílio e a volta estiveram, em geral, associados a tempos de felicidade, os testemunhos vão descortinando uma realidade mais complexa e nuançada. Trata-se de um momento delicado (1999a:264-265).

Como Rollemberg constatou em seu trabalho, tal reconciliação com a sociedade não se efetivou para muitos. O retorno produziu diferentes entendimentos. E Celso, assim como outros ex-exilados, fez uma leitura diferente dos significados atribuídos à anistia.

São Paulo [sem data] (carta a uma amiga)

Sábado fui a uma festa do Comitê de Anistia, mil pessoas, a maioria de "retornados". Uma festa surrealista, uma alegria que me pareceu chocante, um entusiasmo indecente e um toque de nostalgia melodramática. As pessoas fazem comparações absurdas entre a vitória sandinista e a volta dos exilados. Parece que ninguém se dá conta, e o que é pior: ninguém quer entender que voltamos derrotados, que houve uma concessão da ditadura. E que se nos permitiram voltar, é porque nos derrotaram, e se houve uma abertura, é porque eles foram os vitoriosos. Mas cada um acredita no que quer acreditar. E assim comemoram a anistia e a abertura como uma vitória das forças populares, um velho discurso tão irreal e alienado como tem sido a esquerda brasileira.

Após a vitória da "oposição" nas eleições legislativas de 1974, iniciou-se no Brasil um movimento impulsionado por setores da sociedade civil em prol da concessão da anistia aos presos políticos e exilados. ${ }^{19}$ É interessante notar que a campanha pela anistia pautou-se pela defesa dos direitos humanos, pela denúncia das torturas praticadas pelo regime militar e pela volta da democracia ao país. Esta pauta, bem diferente daquela produzida pelas organizações armadas (revolução socialista, luta anti-imperialista etc.), promoveu uma certa unidade entre alguns militantes exilados, setores da sociedade civil brasileira e agências internacionais, pressionando o governo brasileiro a implementar uma gradual abertura política (Quadrat 2008; Estevez 2012).

No final dos anos 1970 e início dos anos 1980, os romances, os testemunhos e os depoimentos produzidos e prestados por ex-militantes ganharam muita visibilidade e interesse público. ${ }^{20}$ Como bem assinalou Rollemberg:

As autobiografias se multiplicavam e vendiam. Algumas foram bestsellers. As reportagens sobre os exilados tornaram-se frequentes [...] Mas, nos primeiros 
anos, não deixou de pairar no ar a mistificação do exilado, até porque era um personagem que estava sendo conhecido - e construído - como um viajante que vem de outras terras, de uma longa distância, e conta, no centro da roda, o que viu (1999a:16).

Assim, a partir da segunda metade dos anos 1970, um longo processo de reordenamento político organizou as novas percepções e interpretações sobre o período ditatorial, ajudando a consolidar os caminhos futuros. E, com a implementação da lei de anistia, iniciava-se então uma disposição das memórias, das experiências vividas pelos exilados e não exilados, pelas forças políticas que se reagrupavam em um novo contexto, com novos personagens, possibilidades e sentidos. ${ }^{21}$ Era preciso mudar a estratégia e a tática política, era preciso construir um novo projeto, com outros valores e mecanismos de comunhão, oferecendo um novo sentido à tradição da militância política de esquerda e, principalmente, reintegrando-a ao fluxo do cotidiano. Era necessário, portanto, sistematizar e classificar essas experiências e memórias sobre os anos de ditadura civil-militar agora em uma perspectiva mais distanciada e que, acima de tudo, transformasse a "ditadura em história e objeto de estudo"(Martins Filho 2002:196). Assim como os eventos do passado começaram a ser interpretados, as experiências vividas pelos seus diferentes protagonistas também passaram a ser entendidas, ordenadas, classificadas e explicadas.

No entanto, esse "novo" tinha que estar ancorado em um passado, em uma história, em uma memória, algo que os indivíduos pudessem compartilhar, socializar, reordenar as identidades fragmentadas, rompidas e redefinidas no exílio e em que conseguissem se amparar. Para muitos, esse novo projeto poderia efetivar-se através da criação de um "partido de massa", um partido formado pela "classe trabalhadora", abandonando (ou suspendendo temporariamente) teses clássicas - que orientaram alguns militantes — de "partido de vanguarda", "partido de quadros". ${ }^{22} \mathrm{O}$ fundamental era instituir um novo sentido, político e existencial, à experiência revolucionária, e atualizar seus "mitos coesionadores", nos termos de Aarão Reis Filho (1999), ou os "sentimentos revolucionários", nos termos de Ridenti (2010b).

O debate estava aberto e a "euforia" com a anistia ganhava outros contornos e ingredientes. Afinal, para muitos, esse "novo projeto" poderia ser sentido como uma continuidade, um amadurecimento das estratégias produzidas no passado recente, o abandono da luta armada, de noções como "guerrilha", "foquismo", "guerra continuada" etc. E poderia produzir novos processos políticos e acúmulos, sem renunciar aos princípios e aos valores que mobilizaram diferentes indivíduos em tempos e contextos históricos 
(Silva 2008). Situar essas novas opções em um processo temporal permitiria estabelecer um elo de continuidade das experiências vividas e experimentadas de forma singular, mas com seus sentidos e significados compartilhados pelo coletivo. Teríamos, como afirmou Ricoeur, o "milagre" da integração entre subjetividades distintas, pois "a experiência experienciada, como vivida, permanece privada, mas seu sentido, a sua significação, torna-se público" (Ricoeur 1976:27). A tradição sobreviveria, mesmo diante do sentimento de "derrota" amplamente reconhecido e compartilhado.

Carta (gravada) para Ana (segunda esposa), 1982

Eu continuo pelo menos orientando minha vida em função das opções políticas mais gerais, pelo menos e isso não corresponde necessariamente e sempre a uma atitude militante mais consequente, mas pelo menos continua sendo a referência principal. A única razão que tenho de continuar no Brasil, e realmente a única, é que agora eu creio que há uma possibilidade muito concreta de construção de um partido de massa, e que esse partido é o PT. [...] Eu te diria, ou construímos o PT em São Paulo ou não construímos em nenhuma parte.

Em certa medida, Celso estava se integrando neste projeto, nesse momento de reconstituição da tradição revolucionária. O projeto de construção do "partido de massas" parecia ser concretamente um canal capaz de restabelecer um sentido afetivo e existencial à experiência humana, de restituir dialeticamente a relação entre os sentidos das subjetividades (proporcionados pela experiência dos movimentos revolucionários) e as necessidades da realidade concreta, permitindo a reintegração na vida social.

Alguma coisa aconteceu nesse processo que fez com que Celso se distanciasse gradativamente de tal projeto, da possibilidade de associação do instante presente com as tradições do passado e de que houvesse o "milagre" da integração entre as subjetividades e a sua publicização.

Fragmentos de cartas (1980-1982)

Acabo de chegar do Rio, seis horas de viagem de ônibus, um calor terrível e entro em uma cidade fria e úmida, sem sol. Ainda me parecem estranhas essas mudanças de temperatura a cada dois ou três dias. Voltei meio intoxicado, cansado, de saco cheio.

No puedo evitar una sensación de distancia. Las cosas me parecen irreales y mi desarraigo es definitivo. La única cosa que me vincula a este país es un proyecto político, y nada mas. 
[...] Reuniões políticas muito confusas e noites inteiras com os amigos. Muita cachaça, muita música e, sobretudo, uma sensação crescente de que não tenho nada, ou tenho muito pouco a ver com tudo isso.

Carta a Flavia (filha), 1982

Flau querida é estranho te escrever hoje. Tenho a impressão de que estivemos muito longe, muito distanciados nesses dois anos. É como se o fato de vivermos no mesmo país nos tivesse afastado. Claro que a culpa é minha. Desde que voltei para o Brasil (e como me arrependo de ter voltado) tive uma dificuldade enorme de me reintegrar. E essa dificuldade aumenta à medida que passa o tempo, hoje é maior do que há seis meses atrás, muito maior de que há um ano. Quando resolvi vir para Porto Alegre, pensei que aqui seria mais fácil essa adaptação. Outro erro. Desde que voltei para cá as coisas ficaram piores. Bem piores. Em São Paulo tinha um emprego precário, aqui não tenho nenhum. O cotidiano é insuportável e não há esperanças de que alguma coisa se modifique. O que pretendo não é ficar me queixando da vida. Também não estou tentando me desculpar ou justificar. O fato é que a minha dificuldade de adaptação, minhas neuroses e minha angústia, além de complicarem minha vida, complicam a das pessoas que eu amo, dificultam o relacionamento com as pessoas e com a vida, e me transformaram em um cara amargo, cético.

Texto Celso (1984 - dois meses antes da sua morte)

Não tenho mais aquele empurre de antes. Não me passa mais pela cabeça formar um grupo político. Não consigo imaginar que eu possa ter uma ação política mais ativa, mais combativa, como a criação de um grupo de esquerda radical dentro de um dos partidos existentes. Não vou conseguir. Para mim não foi possível.

Como entender essa virada? Com quais elementos podemos operar para ter acesso, mesmo que de forma superficial, ao sentido atribuído por Celso aos últimos anos de sua vida, à sua experiência, às suas projeções e expectativas do futuro?

Tais perguntas podem ajudar a entender as interpretações e os significados produzidos pelos amigos e familiares, da ação empreendida nos Moinhos de Vento no dia 04 de outubro de 1984 por Celso e Nestor. O desafio destas interpretações era estabelecer algum tipo de elo entre a biografia dos dois - visto não se tratar de biografias meramente individuais, pois tanto Celso quanto Nestor carregavam experiência, valores e afetos, sentimentos e emoções produzidos historicamente e compartilhados com muitos outros - e as circunstâncias que os levaram à morte. Como entender uma ação com as características e as particularidades do ato 
praticado e, ao mesmo tempo, atribuir ao indivíduo uma coerência, uma ética e uma moral históricas?

Se nos anos de 1960/1970 os "mitos coesionadores" sobre a inevitabilidade da revolução, ou mesmo a noção de "espírito revolucionário", serviram para identificar os aspectos compartilhados por uma geração de militantes políticos, nas décadas subsequentes foram criados novos mitos para explicar por que a "revolução inevitável"não aconteceu, "por que as massas não aderiram ao projeto revolucionário, qual foi o caráter da resistência à ditadura" (Aarão Reis 1990:19). Era necessário produzir explicações sobre os "fracassos", os "desvios", os "erros estratégicos", não apenas entender a derrota, mas também os efeitos e as consequências das diversas violências a que foram submetidos os militantes políticos. Mas estas explicações também tinham que restabelecer novos mitos e novas formas de perpetuar uma herança revolucionária.

Em uma aliança discursiva, às análises e interpretações da historiografia e do testemunho somam-se as análises de caráter mais psicanalítico, que buscam estabelecer novas dimensões para os entendimentos da experiência humana (Seligmann-Silva 2008; Ribeiro 2005; Sarlo 2007). Para esta literatura, as situações de exílio, clandestinidade, morte, desaparecimentos etc. causam níveis de tensão e sofrimento e produzem uma "experiência traumática". Essas experiências e os possíveis traumas causados por "situações limites" gerariam um tipo de "sentimento de derrota", uma sensação de "inadequação", dificultando o reingresso na vida cotidiana após o abandono da luta armada ou do retorno do exílio (Ribeiro 2005). E as dificuldades do processo de reinserção são descritos como consequências e efeitos do nível de envolvimento afetivo, moral e sentimental empenhado nos embates revolucionários (Thiesen 2011; Costa 2004; Ribeiro 2005; Fico 2001).

Diante do que foi exposto, acredito que às interpretações produzidas logo após a morte de Celso possam ser incorporadas outras. Em que pese o clima na época de instabilidade política, medo, insegurança, fragmentação das esquerdas etc., acredito que as interpretações suscitadas pelo evento nos Moinhos de Vento não se fundaram apenas no receio do impacto político de associar um suposto assalto às práticas políticas da esquerda e, com isso, comprometer a viabilidade eleitoral e política dos partidos progressistas. Considero que tanto o ato de Celso como a postura dos amigos e as interpretações produzidas sobre sua morte se configuraram como movimentos contraditórios de um mesmo processo de busca existencial.

Se aceitarmos os diferentes sentidos, aqui analisados, produzidos pela experiência de Celso, poderemos sugerir que sua última experiência explicita uma incompatibilidade não apenas com a nova realidade política conjuntural, 
mas também uma rejeição a estabelecer um elo de continuidade entre o conjunto das suas experiências e vivências anteriores e as que se colocavam no seu presente. O que foi derrotado então não foi apenas um "projeto político" ou uma "visão de mundo", mas uma possibilidade existencial de estar no mundo. No outro oposto, encontravam-se os amigos. Para eles, talvez o que tivesse sido derrotado tenha sido, sim, um projeto político, projeto este que, no entanto, pôde ser reconstruído, redefinido e mesmo atualizado.

\section{Construindo novas narrativas}

As emoções e os sentimentos que foram provocados pelo filme Diário de uma busca em cada um dos espectadores eram únicos e singulares, mas se inscreviam na procura pela reconstituição não apenas de uma narrativa sobre a sucessão dos eventos pós-golpe militar de 31 de março de 1964, mas também pelo estabelecimento de elos com as ações do presente. Talvez isso ajude a entender porque em 2012, no ato de comemoração dos 48 anos da "revolução" de 1964 no Clube Militar, jovens projetavam trechos do filme no muro deste prédio como forma de protesto.

Em tempos de Comissão Nacional da Verdade (CNV), assiste-se, mesmo que de forma gradual, a um rearranjo político institucional, um reordenamento das posições políticas, das memórias, dos esquecimentos, das trajetórias singulares e coletivas que estiveram e ainda estão dispersas, fragmentadas e ocultas, contando e (re)contando experiências e eventos que marcaram os anos de 1960 a 1980. O que parece estar em disputa neste contexto é definir quais experiências e trajetórias fornecerão os atributos para a constituição dessa "nova" memória, quais narrativas serão selecionadas e quais sentidos e entendimentos serão atribuídos ao passado. Ao mesmo tempo, esses embates devem estabelecer processos que garantam uma certa unidade, um certo consenso. ${ }^{23}$

Se a luta pela aquisição de bens simbólicos para disputar a interpretação do passado estabelece um elo de integração entre agentes tão diversos, o que os diferencia e os singulariza são exatamente os sentidos e os significados atribuídos ao passado e a contínua produção de memórias díspares. Nesta perspectiva, poderíamos falar, segundo Thomas e Znaniecki, que existem vínculos "que une[m] pessoas além e acima de qualquer vínculo formal" (apud Turner 2008:40) e que, a partir destes vínculos, são produzidos significados e sentidos distintos. Esta capacidade de produzir vínculos não formais, não racionais, emocionais, afetivos obedece, portanto, a outras disposições e a distintos processos que colocam os indivíduos e/ou os agentes em planos diferentes. 
Os longos embates pela interpretação do passado, pela seleção do que esquecer e do que lembrar promovidos nas últimas três décadas, dos quais participaram diferentes organizações, instituições e indivíduos, estabeleceram um novo patamar nas disputas pelo significado desse passado.

Um bom exemplo deste tipo de embate foram as discussões geradas a partir do lançamento do filme, em 1997, de Bruno Barreto, O que é isso companheiro? (inspirado no livro autobiográfico, de 1979, do ex-militante do Movimento Revolucionário 8 de Outubro (MR-8) e ex-exilado político Fernando Gabeira). Segundo Rollemberg (2006:83), o filme teria produzido "uma espécie de unanimidade da opinião pública" sobre o que teria sido a luta armada, em especial sobre os dilemas, as atitudes e os comportamentos dos militantes durante o período do sequestro. Em particular, a versão apresentada por Fernando Gabeira sobre os eventos do dia a dia do sequestro do embaixador norte-americano Charles Elbrick, em 1969, produziu diferentes controvérsias e outras narrativas e interpretações (Aarão Reis Filho 1997). Outro exemplo na contramão dessa "unanimidade" foi a publicação do livro do ex-militante da Ação Libertadora Nacional (ALN), Carlos Eugénio Paz, Viagem à luta armada: memórias romanceadas (1995), que provocou reações mais silenciosas e ambíguas ao trazer à tona lembranças, memórias e temas mais complexos de serem enquadrados em uma grande narrativa das experiências da esquerda armada no período, pois apresentava questões sobre justiçamento, cotidianos de violência etc.

No outro extremo, as memórias produzidas por militares aposentados expostas através de testemunhos reproduzidos em Castro, D'Araújo e Soares e (1994) e D'Araújo e Castro (1997), ou ainda na grande imprensa, como foi o caso do depoimento do general Newton Cruz, ex-chefe do Sistema Nacional de Informação (SNI). E também em livros autobiográficos, tais como Um híbrido fértil (1996), de Jarbas Passarinho (ex-ministro do governo Castelo Branco); A verdade sufocada, a história que a esquerda não quer que o Brasil conheça (2006), de Carlos Alberto Brilhante Ustra (ex-chefe do DOI-CODI de São Paulo); Memórias de uma guerra suja (2012), de Cláudio Guerra (ex-chefe do DOPS no Rio de Janeiro). As memórias de ex-militares são um movimento de formulação de um contradiscurso e um contraponto às memórias produzidas pelos militantes ou ex-militantes de esquerda.

Como bem sinalizou Martins Filho, "a guerra da memória se constituiu justamente num intenso intercâmbio de versões sobre os aspectos mais polêmicos da ditadura do pós-64" (2002:182). E em tempos de CNV, estas disputas se ancoram nos novos sentidos que vêm sendo construídos nas performances das audiências públicas promovidas pelas comissões estaduais e locais, na publicização de documentos até então indisponíveis sobre a 
estrutura repressiva que foi montada sob o governo ditatorial e na revisão de certos fatos, como a mudança do atestado de óbito do jornalista Vladimir Herzog ou das circunstâncias da morte de alguns militantes políticos, dentre outros fatos e eventos.

A tensão promovida neste novo momento da "guerra de memórias" opera como uma relação de antagonismo e complementaridade, na qual o que estaria em disputa seriam os processos de salvaguarda dos acontecimentos ou, como afirma Pollak, "em tentativas mais ou menos conscientes de definir e de reforçar sentimentos de pertencimento e fronteiras sociais" (1989:7).

São nesses embates que as estratégias conscientes e/ou inconscientes de construção/desconstrução dos marcadores de identificação dos grupos tornam-se mais visíveis, e as trajetórias, as memórias, as experiências, os eventos, os fatos e os contextos - singulares - ganham novas dinâmicas, deixando de ser apenas experiências vividas e únicas para serem experiências vividas e compartilhadas. Os embates revelam o conjunto de referências que orientam o lugar onde determinadas memórias, biografias e experiências serão indexadas e classificadas. ${ }^{24}$ Enquanto políticas da memória, estes embates fornecem os instrumentos para a produção da memória coletiva.

Entretanto, ao olharmos para determinadas biografias/trajetórias, ou seja, para as experiências vividas, sentidas, desejadas e projetadas de indivíduos singulares, percebemos que existem ações que se constituem nos interstícios dos "princípios geradores e organizadores de práticas e representações" (Bourdieu 2009:87). E que se afastam, portanto, dos direcionamentos e dos possíveis enquadramentos impulsionados pelos/nos embates, fornecendo um campo mais amplo de compreensão da experiência humana para além da sua razão prática. Isto não quer dizer que estas biografias não sejam indexadas ou classificadas segundo um determinado sentido, mas que sua compreensão talvez não obedeça aos mesmos princípios.

Recebido em 08 de dezembro de 2013

Aprovado em 13 de março de 2014

João Paulo Macedo e Castro é professor da Universidade Federal do Estado do Rio de Janeiro - UNIRIO. Email: <castro.jpm@gmail.com> 


\section{Notas}

${ }^{1}$ O filme foi lançado em 2010 na competição oficial do Festival de Gramado, no qual recebeu o prêmio da crítica especializada e de melhor documentário do júri dos estudantes. No ano de 2010 ainda receberia os prêmios: melhor documentário no Festival do Rio; melhor documentário no Festival de Biarritz; melhor filme do Festival de Cinema de Punta del Leste.

${ }^{2}$ Lei 6.683 de 28 de agosto de 1979, que concede anistia e dá outras providências (http://www.planalto.gov.br/ccivil_03/leis/L6683.htm).

${ }^{3}$ Utilizo a noção de "experiência singular" (na experience) tal qual formulada por John Dewey: "temos uma experiência singular quando o material vivenciado faz o percurso até sua consecução. Então, e só então, ela é integrada e demarcada no fluxo geral da experiência proveniente de outras experiências. Conclui-se uma obra de modo satisfatório, um problema recebe sua solução. Um jogo é praticado até o fim, uma partida de xadrez, conduzir uma conversa, escrever um livro ou participar de uma campanha política, conclui-se de tal modo que esse encerramento é uma consumação e não uma cessação. Essa experiência em si é um todo e carrega em si seu caráter individualizador e sua autossuficiência. Trata-se de uma experiência" (Dewey 2010:109-110).

${ }^{4}$ Dilthey faz uma oposição entre experiência (Erlebnis) como uma dimensão pré-reflexiva e pessoal, uma "experiência vivida", ou uma "vivência", e experiência (Erfahrung) como processo de aprendizado sensorial e cognitivo, produzindo o que Gadamer denominaria de consciência histórica: "talvez pudéssemos dizer que a consciência histórica não é tanto um apagar-se a si mesmo, mas uma posse de si mesmo mais elevada, e é isso o que distingue a consciência histórica de todas as demais formas do espírito" (1997:316).

${ }^{5}$ Durante seu exílio na França, Celso trabalhou na gráfica do jornal Rouge, editado pela LCR.

${ }^{6}$ Referências dessa natureza aparecem em praticamente todos os comentários publicados e divulgados pela grande imprensa. Em especial, em texto de Escorel para a revista Piauí, 2011; de Oricchio Zanin, em O Estado de São Paulo, 27 de outubro de 2010; e de Amir Labaki, São Paulo, no Valor Econômico 26/08/2011.

${ }^{7}$ Na conferência de imprensa do Festival de Gramado de 2010, o público foi formado basicamente por jornalistas. No FestRio 2010, o público foi mais diversificado, com a presença de jovens interessados no tema do regime militar. Já na cidade de Porto Alegre, o filme foi lançado no Sindicato dos Bancários, um dos principais da cidade, e presidido por integrantes da tendência Democracia Socialista do Partido dos Trabalhadores (fundada por alguns integrantes do extinto POC - partido em que militou Celso nos anos 1970). A plateia era composta essencialmente por jovens, 
militantes e ex-militantes, e contou com a presença de algumas das principais lideranças do Partido dos Trabalhadores, tais como o ex-governador do Estado do Rio Grande do Sul, Olívio Dutra, do ex-prefeito e colega de Celso nos anos do colégio, Raul Pont, e do ex-deputado Flavio Koutzii, citado por Celso em carta de 1973. Nesse espaço, o debate levantou diferentes dimensões, afetivas e políticas, produzidas pela experiência de radicalização da luta política, e também questões sobre os embates políticos pós-ditadura, os avanços e os limites da democracia política, a importância de rever e de punir os crimes praticados pelo regime militar e sobre as possibilidades de revisão/reparação histórica proporcionada pela instalação da Comissão Nacional da Verdade (CNV). Já no debate realizado em 2012 no Instituto Moreira Salles, no Rio de Janeiro, o público era composto de ex-militantes e ex-exilados e, apesar dos temas serem semelhantes aos do debate no Sindicato dos Bancários, a ênfase recaiu também sobre as dimensões afetivas: os vínculos que foram rompidos, as relações familiares, as emoções dos filhos etc.

${ }^{8}$ Como lembra Bourdieu (2008), "a narrativa, seja biográfica ou autobiográfica, [...] propõe eventos, que, apesar de não se desenrolarem todos, sempre, na estrita sucessão cronológica [...], tendem a, ou pretendem organizar-se em sequências ordenadas e de acordo com relações inteligíveis. O sujeito e o objeto da biografia (o entrevistador e o entrevistado) têm de certo modo o mesmo interesse em aceitar o postulado do sentido da existência contada (e, implicitamente, de qualquer existência)" (Bourdieu 2008:74).

${ }^{9} \mathrm{O}$ conjunto das informações dispostas nesta seção foi retirado de matérias publicadas nos jornais Zero Hora (de grande circulação na região Sul do país), Folha de São Paulo, Isto é, Pasquim, e nos depoimentos e documentos componentes do relatório policial.

${ }^{10}$ Como lembram alguns ex-militantes em depoimentos prestados a Ridenti (2010a:252-274) e Rollemberg (1999a, caps. 9 e 10).Os termos fracasso, derrota, desilusão também aparecem nas autobiografias produzidas por ex-militantes, como Renato Tapajós, Herbert Daniel, Fernando Gabeira, Alfredo Sirkis, dentre muitos outros, para explicar as escolhas, as atitudes e os comportamentos de outros militantes após o endurecimento da repressão política em meados dos anos 1970.

${ }^{11}$ Estou me referindo a um tipo de militância praticada nos anos 1960 e 1970 que se amparava em uma "narrativa de longa duração", nos termos de Velho (1995), e que tinha nos movimentos revolucionários do século XIX e XX seus principais referenciais éticos, morais e políticos. Para uma discussão em uma perspectiva internacional, ver Lowy e Sayre (1995) e Hobsbawm (2003). Para o caso brasileiro, Ridenti (2010b) utiliza a noção de "espírito revolucionário" para marcar a convergência de diferentes sentimentos produzidos nos anos de 1960 no Brasil que tinham como proposta variadas ideias de revolução (social, política, estética etc.).

${ }^{12}$ Em depoimento para o filme Diário de uma busca, 26 anos depois, Jean Marc afirmaria que à época rebateu as interpretações que estavam sendo formuladas, pois 
queria tanto preservar uma imagem de Celso para mim e para minha irmã como também para ele mesmo.

${ }^{13}$ As fontes utilizadas e analisadas para este artigo tratam especificamente da trajetória de Celso Castro. Neste sentido, é importante alertar que certas interpretações e hipóteses levantadas dizem respeito apenas a ele, e não a Nestor Herédia.

${ }^{14}$ Depoimento concedido para o filme Diário de uma busca.

${ }^{15}$ Esta percepção é compartilhada por outros ex-militantes. Ver Ridenti (2010a).

${ }^{16}$ Sobre os diferentes sentidos de comunhão, ver Turner (1974) e Velho (1993).

${ }^{17}$ De acordo com Ridenti (2010a:264), no período de endurecimento da repressão política "o sacrifício pessoal e, no limite, a morte iam perdendo o sentido revolucionário de conquista da vida, para ganhar contornos de obrigação moral com os companheiros caídos e com a sobrevivência do próprio grupo guerrilheiro".

${ }^{18}$ Um bom exemplo dessas sensações pode ser encontrado no livro $K$. , de Bernardo Kucinski (2011), que aborda de forma ficcional a busca de um pai pela filha desaparecida nos anos 1970.

${ }^{19}$ Esse movimento foi encabeçado especialmente pelo Movimento Feminino pela Anistia (MFPA), sendo posteriormente ampliado com a criação, em 1978, dos Comitês Brasileiros pela Anistia (CBAs) e a participação do Movimento Democrático Brasileiro (MDB), da Ordem dos Advogados do Brasil (OAB), da Associação Brasileira de Imprensa (ABI) e do Conselho Nacional dos Bispos do Brasil (CNBB). Ver Greco 2003; Rodeghero 2009; Araújo 2012.

${ }^{20}$ Em 1977, Renato Tapajós publicou seu livro Em câmara lenta e, em julho do mesmo ano, foi preso por agentes do DOPS. A prisão de Tapajós produziu uma mobilização intensa pela sua liberdade, promovida por setores da sociedade civil e amplamente coberta pela imprensa. Em agosto de 1977 foi solto e em maio de 1979 seu livro apareceu na $9^{\circ}$ posição dos mais vendidos, em ranking publicado pela revista Veja. No mesmo ano, Fernando Gabeira lançou o livro O que é isso companheiro e, depois de sete semanas entre os dez mais vendidos, alcançou o primeiro lugar. No ano seguinte, o livro foi traduzido para o francês, o alemão e o inglês, alcançando na sua $16^{a}$ edição a venda de 120.000 exemplares no ano. Ainda nesse ano, Gabeira ganhou o prêmio Jabuti de melhor livro na categoria biografia e/ou memória (Silva 2009:141-166).

${ }^{21}$ Além das citadas anteriormente, outras narrativas autobiográficas de caráter memorialístico foram publicadas, tais como A chacina da Lapa, de Reynaldo Laforgia (1976); Cadeia para os mortos, de Rodolfo Konder (1977); Memórias do exílio-Brasil 1964-199?, de Uchôa Cavalcanti (1978); Tortura, a história da repressão política no Brasil, de Antonio Carlos Fon (1979); Os carbonários - memória da guerrilha perdida 
(1980), de Alfredo Sirkis; Tirando o capuz (1981), de Álvaro Caldas; Batismo de sangue. Os dominicanos e a morte de Carlos Marighella (1981), de Frei Beto; Passagem para o próximo sonho (1982), de Herbert Daniel; Em busca do tesouro (1982), de Alex Polari; e A fuga (1984), de Reinaldo Guarany, dentre outros. Na década seguinte, esse tipo de literatura, denominada por Seligmann-Silva (1999) de "literatura do eu", produziria uma "torrente de memórias da vida real", aumentando consideravelmente os registros e as narrativas da experiência do regime militar. Já as vivências da luta armada e da atuação das diferentes organizações de esquerda também começaram a ser objeto de reflexão científica. Os trabalhos de Jacob Gorender, Combate nas trevas - a esquerda brasileira: das ilusões à luta armada (1987); de Daniel Aarão Reis, A revolução faltou ao encontro. Os comunistas no Brasil (1990) e de Marcelo Ridenti, O fantasma da revolução no Brasil (1993), podem ser considerados pioneiros nas reflexões sobre diferentes aspectos da experiência política das organizações de esquerda nos anos 1960/1970.

${ }^{22}$ Existe uma farta literatura que aborda a mudança das estratégias políticas no período de final dos anos 1970 e início dos anos 1980, como em Rollemberg (2007b), Montenegro (2011), Sarti (1998).

${ }^{23}$ Como nos alerta Pollak, "em vários momentos, Maurice Halbwachs insinua não apenas a seletividade de toda memória, mas também um processo de 'negociação' para conciliar memória coletiva e memórias individuais" (1989:3).

${ }^{24}$ Como lembra Bourdieu (2009), existe um "campo de possibilidades" limitado que permite ao indivíduo circular com certa liberdade por entre os referenciais fornecidos pela estrutura de significado ao qual está vinculado, permitindo que faça escolhas, defina seus objetivos e estabeleça uma trajetória percebida como única, singular. Esta fórmula é extremamente útil para pensar as estratégias acionadas pelos diferentes agentes nos embates para a interpretação do passado, para selecionar os eventos marcantes, as lembranças, instituir os esquecimentos, posicionar e reposicionar os indivíduos e os grupos com suas trajetórias e biografias singulares e produzir o que Michel Pollak chamou de "enquadramento da memória": "Para que nossa memória se beneficie da dos outros, não basta que eles nos tragam seus testemunhos: é preciso também que ela não tenha deixado de concordar com suas memórias e que haja suficientes pontos de contato entre ela e as outras para que a lembrança que os outros nos trazem possa ser reconstruída sobre uma base comum" (1989:3). 


\section{Referências bibliográficas}

AARÃO R. Filho, Daniel. 1990. A Revolução faltou ao encontro. Os comunistas no Brasil. São Paulo: Brasiliense.

_ (org.). 1997. Versões e ficções - o sequestro da história. São Paulo: Perseu Abramo.

; RIDENTI, Marcelo et al. 2004. O golpe e a ditadura militar: quarenta anos depois (1964-2004). Bauru: Edusc.

ARAÚJO, Maria Paula N. 2012. "Uma história oral da anistia no Brasil: memória, testemunho e superação". In: __ ; A. Montenegro, C. S. Rodeghero (orgs.), Marcas da memória: história oral da anistia no Brasil. $1^{\mathrm{a}}$. ed. Recife: Editora da Universidade Federal de Pernambuco. vol. 1. pp. 53-95.

BOURDIEU, Pierre. 2009. O senso prático. Petrópolis: Vozes.

2008. Razões práticas. São Paulo: Papirus.

CAMURÇA, Marcelo. 1994. Os "melhores filhos do povo". Um estudo do ritual e do simbólico numa organização comunista: o caso do MR8. Tese de doutorado em Antropologia Social, Rio de Janeiro, Museu Nacional-UFRJ.

CASTRO, Celso; D'ARAUJO, Maria Celina \& SOARES, Gláucio (orgs.). 1994. Visões do golpe. A memória militar de 1964. Rio de Janeiro: Relume Dumará. - \& D'ARAUJO, Maria Celina (orgs.). 1997. Ernesto Geisel. Rio de Janeiro: FGV.

CATELA, Ludmila da S. 2001. Situação limite e memória. A reconstrução do mundo dos familiares de desaparecidos da Argentina. São Paulo: UCITEC. COSTA, Célia Leite. 2004. "Acervos e repressão". Seminário 40 anos do Golpe de 1964. Rio de Janeiro: 7 Letras.

DEWEY, John. 2010. Arte como experiência. São Paulo: Martins Fontes.
DIEHL, Astor. 2002. Cultura historiográfica: memória, identidade e representação. Bauru: EDUSC.

DILTHEY, Wilhelm. 2010. Introdução às ciências sociais. Tentativas de uma fundamentação para o estudo da sociedade e da história. Rio de Janeiro: Forense.

ESTEVEZ, Ariadna. 2012. "Por uma conceitualização sociopolítica dos direitos humanos a partir da experiência latino-americana". Lua Nova, 86:221-248.

FICO, Carlos. 2001. Como eles agiam: os subterrâneos da Ditadura Militar. Espionagem e polícia política. Rio de Janeiro: Record.

GADAMER, Hans-Georg. 1997. Verdade e método I. Traços fundamentais de uma hermenêutica filosófica. Petrópolis: Vozes.

GORENDER, Jacob. 1987. Combate nas trevas. A esquerda brasileira: das ilusões perdidas à luta armada. São Paulo: Ática.

GRECO, H. 2003. Dimensões fundamentais da luta pela anistia. Tese de doutorado, Belo Horizonte, Universidade Federal de Minas Gerais.

GUELAR, Diana; JARACH, Vera \& RUIZ, Beatriz. 2012. Les enfants de l'exil: Argentine (1975-1984). Paris: Intervalles.

GUERRA, Claudio. 2012. Memórias de uma guerra suja. Rio de Janeiro: Topbooks.

HALBWACHS, Maurice. 1968. La mémoire collective. Paris: PUF.

HOBSBAWM, Eric. 2003. Revolucionários. Ensaios contemporâneos. São Paulo: Paz e Terra.

KUCINSKI, Bernardo. 2011. K. São Paulo: Expresso Popular.

LEVI, Giovanni. 2008. "Usos da biografia". In: Marieta Ferreira \& Janaína Amado (orgs.), Usos \& abusos da história oral. Rio de Janeiro: FGV. pp. 167-182. 
LÖWY, Michael \& SAYRE, Robert. 1995. Revolta e melancolia: o Romantismo na contramão da modernidade. Petrópolis: Vozes.

MARTINS FILHO, J.R. 2002. "A guerra da memória. A ditadura militar nos depoimentos de militantes e militares". Varia História, 28:178-201.

MENEGUELLO, Rachel. 1989. PT: a formação de um partido (1979-1982). Rio de Janeiro: Paz e Terra.

MONTENEGRO, Darlan. 2009. O avesso do príncipe: programa e organização nas origens do Partido dos Trabalhadores. Tese de doutorado em Ciência Política, Rio de Janeiro, IUPERJ.

- 2011. "A esquerda contra a política: organizações guerrilheiras e renúncia à estratégia no período da luta armada". Revista Estudos Políticos, 2:64-84.

NORA, Pierre. 1993. "Entre memória e história: a problemática dos lugares". Projeto História, 10:07-28.

PASSARINHO, Jarbas. 1996. Um híbrido fértil. Rio de Janeiro: Expressão e Cultura. PAZ, Carlos Eugênio. 1995. Viagem à luta armada. Memórias romanceadas. Rio de Janeiro: Civilização Brasileira.

PIETROCOlLA, Luci Gatti. 1996. "Anos 60/70: a violência e o medo na construção da experiência do exílio e da clandestinidade". Revista Brasileira de História, 16(31):303-327.

POLLAK, Michel. 1989. "Memória, esquecimento, silêncio". Estudos Históricos, 2(3):3-15.

QUADRAT, Samantha. 2008. "A emergência do tema dos direitos humanos na América Latina". In: Carlos Fico; Marieta Ferreira; Maria Paula Araujo \& Samantha Quadrat (orgs.), Ditadura e democracia na América Latina. Rio de Janeiro: FGV. pp. 361-394.

RIBEIRO, Maria C. Badan. 2005. Memória, história e sociedade: a contribuição da narrativa de Carlos Eugênio Paz. Dissertação de Mestrado em Sociologia, Unicamp.
RICOEUR, Paul. 2012. Tempo e narrativa. São Paulo: Martins Fontes. - 1977. Interpretação e ideologias. Rio de Janeiro: Francisco Alves. - 1976. Teoria da interpretação: o discurso e o excesso de significação. Lisboa: Edições 70.

RIDENTI, Marcelo. 2010a. O fantasma da revolução brasileira. São Paulo: Unesp.

- 2010b. Brasilidade revolucionária. Um século de cultura e política. São Paulo: Unesp.

RODEGHERO, Carla S. 2009. "A anistia entre a memória e o esquecimento". História Unisinos, 13(2):131-139.

ROLLEMBERG, Denise. 2007a. "Memórias no exílio, memórias do exílio". In: J. Ferreira \& D. Aarão Reis (orgs.), As esquerdas no Brasil. Revolução e democracia (1964...). Rio de Janeiro: Civilização Brasileira. pp. 199-220. - 2007b. "Debate no exílio: em busca de renovação". In: M. Ridenti; D. Aarão Reis Filho (orgs.), História do marxismo no Brasil. Partidos e movimentos após os anos 1960. Campinas: Unicamp. pp. 291-339.

. 2006. "Esquecimento das memórias". In: J. R. Martins Filho (org.), O golpe de 1964 e o regime militar. São Carlos: EdufusCar. pp. 81-91. - 1999a. Exílio. Entre raízes e radares. Rio de Janeiro: Record. - 1999b. "Exílio, refazendo identidades". Revista da Associação Brasileira de História Oral, 2:39-73. . 1992. "Memória e identidade social". Estudos Históricos, 5(10):200-212.

SAID, Edward. 2003. Reflexões sobre o exílio e outros ensaios. São Paulo: Companhia das Letras.

SARLO, Beatriz. 2007. Tempo passado: cultura da memória e guinada subjetiva. São Paulo: Companhia das Letras.

SARTI, Ingrid Piera. 1998. Representação e a questão democrática contemporânea: o mal-estar dos partidos 
socialistas. Tese de Doutorado em Ciência Política, Rio de Janeiro, IUPERJ. SELIGMANN-SILVA, Márcio. 2008. "Narrar o trauma: a questão dos testemunhos de catástrofes históricas". Psicologia Clínica, 20(1):65-82. . 1999. "A literatura do trauma". Cult, 23:40-47. Disponível em: http://acd. ufrj.br/pacc/z/rever/4/ensaios/seligmann.html. Consulta em: 20/04/2014. SILVA, Francisco Carlos. 2009. "Crise da ditadura militar e o processo de abertura política no Brasil, 1974-1985". In: Jorge Ferreira \& Lucilia de A. Delgado (orgs.), O tempo da ditadura: regime militar e movimentos sociais em fins do século XX. Vol. 4. Rio de Janeiro: Civilização Brasileira. pp. 243-282.

SILVA, Mário Augusto M. 2008. Os escritores da guerrilha urbana. Literatura de testemunho, ambivalência e transição política. (1977-1984). São Paulo: Fapesp/Annablume.

SOUZA, Isabel Ribeiro de Oliveira Gómez de. 1988. Trabalho e política: as origens do Partido dos Trabalhadores. Petrópolis: Vozes.

THIESEN, Iclea (org.). 2011. Imagens da clausura na ditadura de 1964. Informação, memória e história. Rio de Janeiro: 7 Letras.

TURNER, Victor. 2008. Dramas, campos e metáforas. Rio de Janeiro. Rio de Janeiro: Eduff.

. 2005[1986]. "Dewey, Dilthey e drama: um ensaio em antropologia da experiência (primeira parte)". Cadernos de Campo,13:177-185.

- 1974. O processo ritual - estrutura e antiestrutura. Petrópolis: Vozes.

USTRA, Carlos Alberto B. 2006. A verdade sufocada, a história que a esquerda não quer que o Brasil conheça. Brasília: Editora Ser.

VELHO, Otávio. 1995. Besta-fera: recriação do mundo. Ensaios críticos de antropologia. Rio de Janeiro: Relume-Dumará. 


\section{Resumo}

Neste artigo, pretendo discutir como a trajetória política de Celso Castro, militante do Partido Operário Comunista (POC) nos anos 1970 e exilado político durante a ditadura militar (1964-1985), foi sucessivamente narrada e indexada após o seu falecimento em um suposto assalto na cidade de Porto Alegre, em 1984. A partir dessas narrativas, busco refletir sobre certos discursos que visam indexar trajetórias, opções e escolhas individuais a determinados esquemas de pensamento e às supostas condições objetivas de tais experiências, uma vez que tais discursos almejariam produzir um sentido de unidade e de continuidade à militância política dos chamados "anos de chumbo" brasileiros. Palavras-chave Trajetória, Ditadura militar, Experiência, Memória, Exílio.

\section{Abstract}

In this article, I intend to discuss how the political trajectory of Celso Castro, a communist militant and political exile during the military dictatorship, was being narrated and recorded after his death in 1984 during an alleged robbery in the city of Porto Alegre. From these narratives, I reflect on how trajectories, options and individual choices are discursively indexed to certain patterns of thought and to the supposedly objective conditions with which these experiences are linked, thereby seeking to produce a sense of unity and continuity in the political activism of the so-called "lead years" of Brazil.

Key words Trajectory, Military dictatorship, Experience, Memory, Exile. 